\title{
熱プラズマを用いる材料プロセッシング 〜非平衡プラズマとの違い〜
}

\author{
渡 辺 隆 行 $^{\mathrm{a}}$ \\ a 東京工業大学 大学院総合理工学研究科 ( 226-8502 神奈川県横浜市緑区長津田 4259-G1-22) \\ Material Processing by Thermal Plasmas \\ $\sim$ Difference between Thermal and Non-Thermal Plasmas $\sim$
}

\section{Takayuki WATANABE ${ }^{\mathrm{a}}$}

${ }^{a}$ Interdisciplinary Graduate School of Science and Engineering, Tokyo Institute of Technology (G1-22, 4259, Nagatsuta, Midori-ku, Yokohama-shi, Kanagawa 226-8502)

Keywords : Thermal Plasma, DC Arc, RF Plasma, Multi-Phase Arc

\section{1. 材料プロセッシングにおける熱プラズマの特徵}

大気圧プラズマの最近の応用技術に関する研究は多方面に 亘っており，たとえば今回の特集でも取り上げているように, 大気圧非平衡プラズマは表面処理を中心に各方面で重要な役 割を担っている。一方, 大気圧で発生するプラズマには，他 にも高温の熱プラズマがあり, 産業的には非平衡プラズマよ りも熱プラズマのほうが従来から広く活用されている。

1 万度以上の高温を有する熱流体であることが熱プラズマ の最も重要な特徴であり，この高温を利用するという観点か ら，プラズマ溶射は表面処理として産業利用が広く展開され ている。他にもプラズマ溶解や製錬，さらに最近はごみ処理 で発生する焼却灰を溶融固化するプロセスにおいて活用され ている。現在の熱プラズマを用いたプロセッシングは，この ような従来のアーク技術の延長として, 熱プラズマの高温を 利用した研究がほとんどである。

大気圧で発生する熱プラズマが本質的に非平衡プラズマと 異なる点は, 高温から一挙に常温までの冷却過程をプロセス として活用できることである。熱プラズマを反応場として材 料プロセッシングに用いる場合には，プラズマが有する 1 万 度以上の高温を利用して原料を蒸発させ，目的物質を得るた めの各種の反応を起こすことができるが，このときにプラズ マの流れの状態による加熱や冷却過程が重要な役割を果たし ている。熱プラズマを用いるプロセッシングでは, 蒸気の冷 却速度を $10^{5} \sim 10^{6} \mathrm{~K} / \mathrm{s}$ 程度にすることができるので，この 高速クエンチングを利用することによって, 熱プラズマ中の 非平衡状態を生み出し, 通常では合成しにくい非平衡相や準 安定相を得ることができる。

大気圧非平衡プラズマと異なる点は, 熱プラズマは大気圧 下においてほぼ熱平衡状態にあることである。熱プラズマで は輻射によって散逸するエネルギーを同じ機構で補うことは 難しいので，厳密な意味での熱平衡状態は実現しにくい。た
だし，中性粒子，イオン，電子の温度がほぼ等しく，組成も 平衡状態に近いプラズマを作ることは比較的容易であり，こ れを局所熱平衡 (LTE, Local Thermodynamic Equilibrium) と呼 んでいる。

大気圧下の熱プラズマは高温部分においてはほぼLTE が 成り立つと考えられているが，熱プラズマでも実際は非平衡 性を有した空間がほとんどであり，最近の熱プラズマプロ セッシングではこのような非平衡性をいかにうまく使うかが 注目されている。熱プラズマは材料プロセッシングにおいて 非常に高いポテンシャルを有しており, 多くのプロセッシン グに利用することが試されてきた。しかし工業生産技術とし て確立したものが少ないのは, 熱プラズマの最大の特徴であ る高温が，逆に材料プロセッシングでは負の作用をもたらす 場合があることが理由のひとつである。つまり, 熱プラズマ の高エネルギーという特徴を保持しながら, そこに非平衡性 を導入して，材料プロセッシングで重要な役割を果たすラジ カルなどの活性化学種濃度を増大させて, 新しい材料や特異 構造を有する材料の合成技術の開発が期待されている。

プラズマの非平衡性を引き起こす要因のうち, 熱プラズマ で重要なのは反応非平衡性と熱的非平衡性である ${ }^{1,2)}$ 。熱プ ラズマの研究では, プラズマの熱流動現象は詳細に検討され てきたが，プラズマの反応非平衡性と熱的非平衡性を材料プ ロセッシングとして検討した例は必ずしも多くない。

反応非平衡性とは, 反応性ガスを用いたプロセスにおける 解離, 再結合, 電離などの反応が熱平衡状態にならないこと である。反応非平衡性が問題となるかどうかは, 対流・拡散 による輸送速度と反応速度との関係で決まる ${ }^{3)}$ 。高温のプラ ズマ流が直接触れる基板や成長中の薄膜表面上の反応非平衡 性は重要な研究課題であるが，これは低温の基板上の境界層 内では, 高温のプラズマ中で生成した化学種の滞留時間が短 すぎるために，組成が平衡状態になることはないからである。 この境界層に存在する非平衡相が最終生成物を支配すること 
が熱プラズマの特徴である。たとえばダイヤモンドの合成で は，境界層内に存在する $\mathrm{CH}_{3}$ などが重要な前駆体となって いる。高温高圧下のみで安定なダイヤモンドを大気圧近傍で 合成できるのは，このような熱プラズマにおける境界層での 活性種の役割が大きい。

また，熱的非平衡性は大気圧非平衡プラズマでは普遍的な 現象であるが，熱プラズマでも熱的非平衡性が顕著に現れる 場合がある ${ }^{4)}$ 。電磁場から受ける加速時間内において, 電子 と重粒子とが弾性衝突により十分なエネルギー变換を行って いれば, 電子温度と重粒子温度はほぼ等しくなる。しかし, 電子から重粒子の運動エネルギーの移動が十分ではない場合 には熱的非平衡性が現れる。熱プラズマの場合には, プラズ マの周辺などで電界が印加された部位で, 電子温度と重粒子 温度が異なる熱的非平衡状態が出現する。

熱プラズマでも実際は非平衡性を有しているとなると, 従 来のように熱プラズマ, 大気圧非平衡プラズマ, 低圧非平衡 プラズマを区別する意味が次第になくなりつつある。しかし， 現状では熱プラズマは依然として熱流体として扱われている 一方で，大気圧非平衡プラズマの熱・物質移動現象を検討し ている研究はほとんどない。本稿では大気圧非平衡プラズマ の特徵と対比しつつ, 熱プラズマを熱流体として扱った場合 の材料プロセッシングに着目し, 熱プラズマの特徴を活かし た材料プロセッシングの現状と今後の課題を, 熱プラズマの 発生方法と特徴と併せて紹介する。

\section{2. 直流放電プラズマによる材料プロセッシング}

直流アーク放電を利用したプラズマジェットおよびプラズ マアークは高出力化や高密度化が可能な実用的かつ工業的な 超高温熱源であり，発生方法が手軽であることから，各種の プロセッシングに広く用いられている。他の熱源と比較する

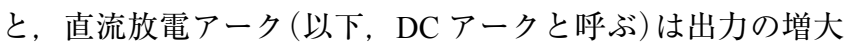
が容易であること, 設備費が比較的廉価であること, DC アー クを発生する装置や技術は確立しており簡単であること, 安 定な放電を長時間持続できること, 被加熱物質の加熱が効率 よくできることなどの利点がある。

しかし DCアークには, 数 $\mathrm{kHz}$ でアークが変動している という本質的な欠点がある。この変動は電極上の陰極点や陽

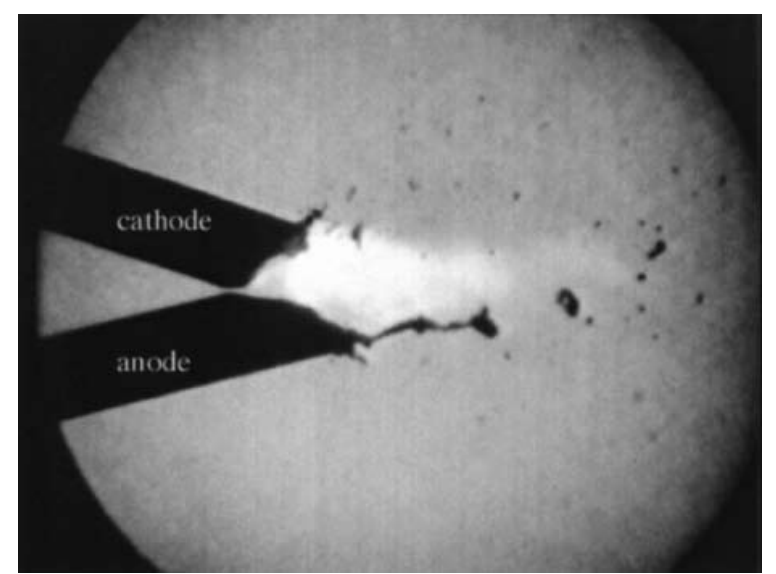

図 1 ワイヤアーク溶射におけるアルミニウム電極からの 液滴生成
極点の周期的な変動に起因しており, DC アークでは避ける ことができないものである ${ }^{5)}$ 。の変動によって， DCアー ク中に供給した原料はその飛行中に DC アークの高温領域だ けではなく，低温領域も通過することになる。これは処理物 質の加熱履歴が均一にならないことを意味している。

電極での変動が顕著に現れるプロセッシングとして，ワイ ヤアーク溶射がある。ワイヤアーク溶射は電極そのものを高 温のアークで溶融させ, 高速のガスでそれらを吹き飛ばすこ とによって溶射皮膜を形成する。このアークの変動は溶融液 滴の生成に大きな影響を与え，その結果，溶射皮膜の特性に 影響を与える。ワイヤアーク溶射のアルミニウム電極，およ び電極から生成した液滴を，レーザーストロボと同期して撮 影した高速度カメラの像(上部：陰極；下部：陽極）を図 $1^{6)}$ に示す。この図から，陰極と陽極からの液滴の生成現象が異 なっていることがわかる。陽極では溶融したアルミニウムが アーク中に伸びて，比較的大きな液滴を生成している。一方， 陰極では細かい液滴が局所的に生成されている。これは陰極 では電流密度が比較的高いために局所的に過熱されるためで ある。

これらの電極の溶融現象は周期的に変動しており, これに 応じてアーク電圧と電流は数 $\mathrm{kHz}$ での特徵的な変動を示す。 測定結果の一例として，電圧と電流の変動を図 2 に，また， この測定值に対してフーリエ解析を行って得られた周波数分 布を図 3 に示す ${ }^{6)}$ 。電圧は $890 \mathrm{~Hz}$ にピークを示しており, この特徴的な周波数はアークの物理的な挙動を現している。 このような数 $\mathrm{kHz}$ 程度のアークの変動は材料プロセッシン グでは避けられず，得られた材料への影響を無視できないが， 逆にアーク電圧や電流の変動現象を測定して, 電極変動を解 析することにより，溶射皮膜の特性を推測する研究も試みら れている ${ }^{6)}$ 。

\section{1 非移行式アーク}

DC アークの発生方式には非移行式と移行式がある。非移 行式アークは，陽極部と陰極部の間でアークを発生させ，ノ ズル部分での熱的ピンチ効果を利用して高温の熱プラズマ流 を得る。プラズマジェットのような非移行式で得られる熱効 率は $30 \%$ 程度と低いが，移行式アークのようにトーチ外部

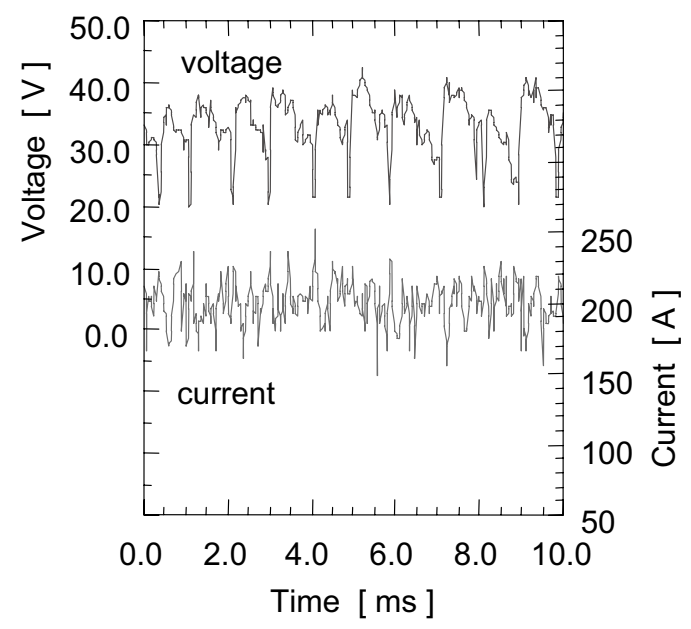

図 2 ワイヤアーク溶射に抒ける電圧と電流の変動 
に陽極が存在しないので，処理する物質の制限がないことか ら，多くの材料プロセシングで利用されている。

プラズマ溶射は非移行式アークを用いる材料プロセッシン グの代表である。プラズマ溶射中のプロセスを定量的に捉え るためのモデリングが行われているが, 実際のプラズマ溶射 では，周囲の空気がプラズマジェットに取り込まれることか ら, 理想的な温度分布とは異なる場合が多い。特にプラズマ ジェットが周囲の空気を巻き込むような乱流現象は, 溶射液 滴への伝熱に大きな影響を与える。プラズマジェットの乱流 構造は図 $4^{7)}$ に示すように特有の構造を有し, ノズル出口に おいて, プラズマジェットが周囲からの低温の空気を渦状に 巻き込む。この渦はリング状の渦を形成し，それぞれが合体 しさらに大きな渦を形成する。これらの渦は変動しているの で，不安定になった渦が別の渦を巻き込むようになり，徐々 に渦が崩壊していく。巻き込まれた低温の空気の渦は, 下流 で小さい渦へと崩壊し, その周囲での混合や拡散が起こるよ うになる。このような混合現象がプラズマジェットの中心部 分で起きるようになると, プラズマジェットのポテンシャル
コア領域が消滅して，完全に混合した乱流領域を形成する。 安定に見えるプラズマジェットも高速度カメラで観察する と, 図 5 に示すように波を打つような不安定挙動を示してい $ろ^{7)}$ 。この現象は, 陽極におけるアークの付着点が軸方向や 周方向に運動していることに起因する。ガスの流れによる下 流に向いた抗力と, 上流に向いたローレンツ力とのバランス によって陽極点は変動している。このアークの陽極点の運動 により, 放電電圧が大きな変動を生じる。このようなプラズ マジェットの不安定現象が原因となって，プラズマの中心に 供給した溶射粒子でさえ, 常にプラズマから安定に加熱され ているとは限らない。プラズマから溶射粒子への伝熱量を推 算しても，大きな誤差を含む可能性があることに注意しなく てはいけない。

プラズマジェットの不安定な変動現象の原因は, プラズマ ジェットで発生した渦などの流れの構造を反映していること から, プラズマジェットの音や圧力の変動, あるいはプラズ マフレームの発光強度変動を周波数解析することによって, プラズマジェットの変動現象が調べられている ${ }^{8,9)}$ 。プラズ

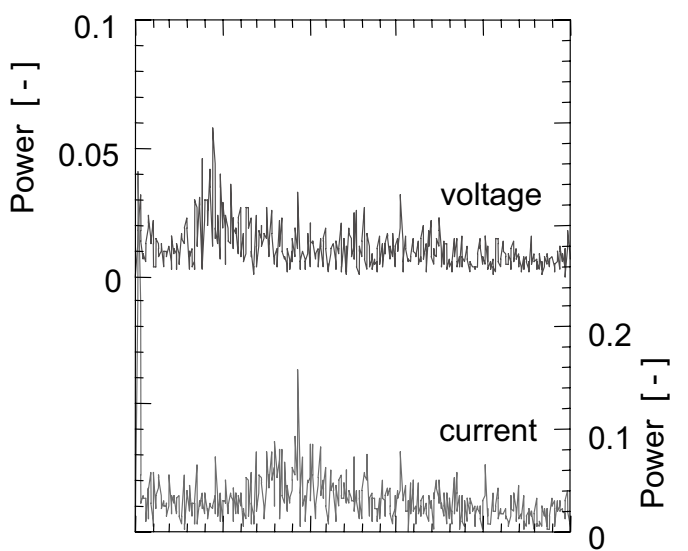

010002000300040005000 Frequency $\left[\mathrm{s}^{-1}\right]$

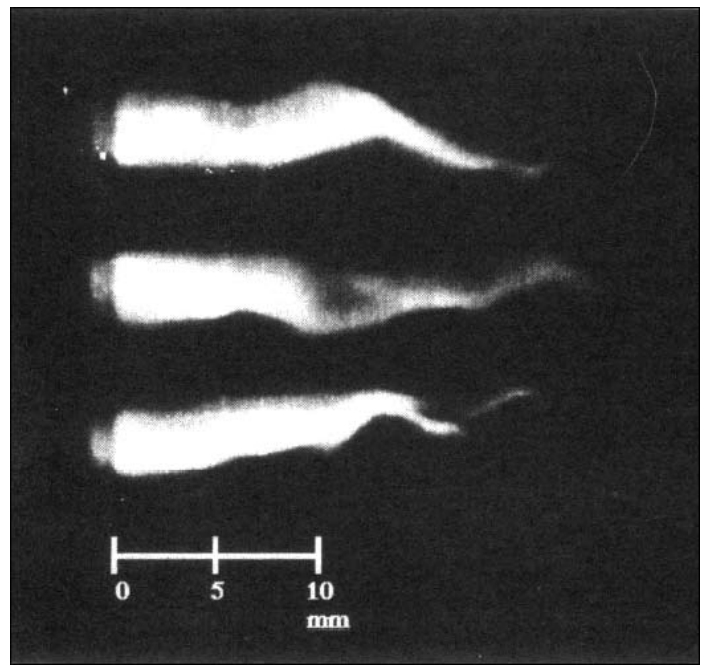

図 5 プラズマジェットの変動の様子
図３ワイヤアーク溶射における電圧と電流変動の FFT 解析

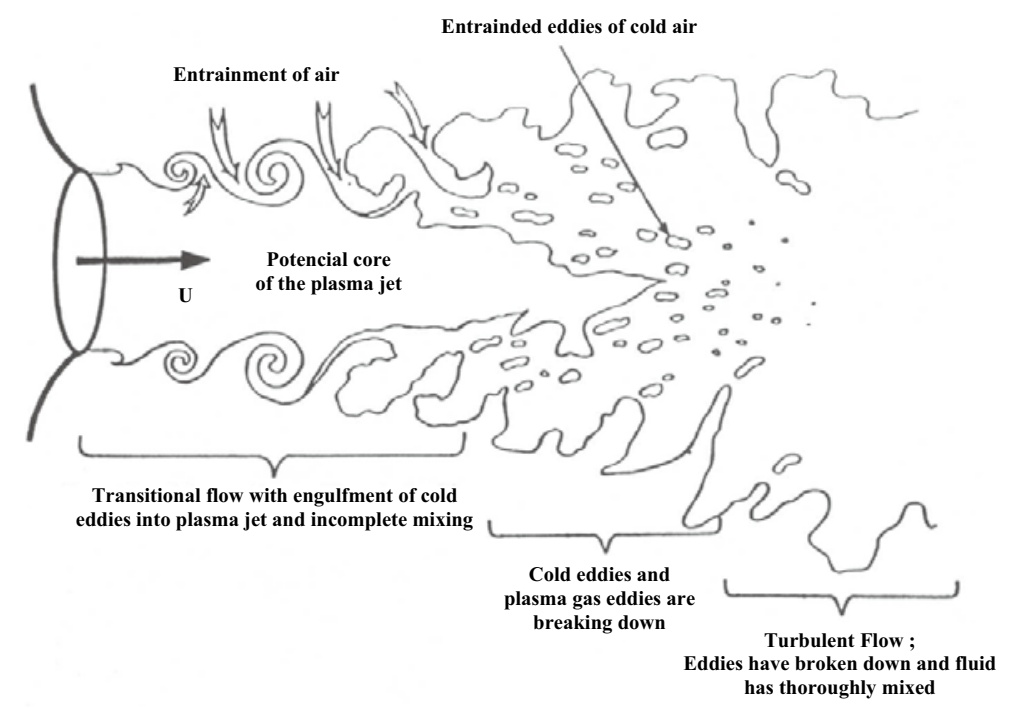


マジェットで発生する音を周波数解析すると，2つの顕著な ピークが測定されているが，このうち $4 \sim 8 \mathrm{kHz} に$ におて見 られる周波数ピークはアーク長の変化や放電電力の変動を示 しており, 同様のピークはアーク電圧変動の周波数解析にお いても見ることができる。また，8～ $12 \mathrm{kHz}$ には，プラズ マジェットの乱流構造に起因すると考えられる周波数ピーク が存在している ${ }^{9)}$

\section{2 移行式アーク}

移行式アークはノズルには電位をほとんどかけず，ノズル から離れた所に置かれた導電性の物質に主たる正電位をかけ る方式である。フリーバーニングアークは移行型アークのよ うに水冷ノズルがなく，棒状の陰極と平板陽極との間に発生 するアークである。この 2 つの方法とも，陽極上に導電性の 処理物質を置き，高温のアークによって原料を溶融させる。 フリーバーニングを用いた材料プロセッシングの代表例とし てはナノ粒子合成があるが，これについては本誌の解説 ${ }^{10)}$ を参考にされたい。

移行式アークの場合には，ノズル下流でもアーク電流が維 持されるために熱効率が $70 \%$ 以上と高いことが利点である が，処理物質は導電性であるという制限があること，対象物 の狭い範囲にアークが集中するので, 均一な加熱が困難であ ることが欠点である。

移行式アークによる重要な現象は, 陽極上に置かれた材料 の蒸発挙動である。特に水素を $50 \%$ 程度まで加えたアーク では，陽極上の溶融金属からのナノ粒子の発生量は飛躍的に 増加する。これはプラズマ中で解離した水素原子が溶融金属 に溶解し，溶融金属中で水素が再結合するときの発熱がナノ 粒子の生成の促進に役立っていると考えられてきた。しかし 単に水素の再結合熱だけでは，この現象を説明することがで きず，水素溶解によって溶融金属の活量が変化すること, 蒸 気圧が大きい水素化物の生成などの可能性がある ${ }^{11)} 。$

\section{3. 高周波熱プラズマによる材料プロセッシング}

高周波 $(\mathrm{RF})$ 熱プラズマは無電極放電の一種であり，電極 物質が不純物としてプラズマ中に混入しないことが特徵であ る。 $\mathrm{RF}$ 熱プラズマトーチの基本構成は, 石英管などの絶縁 材でできた水冷トーチの一端にガス導入部を設け，トーチ外 部の誘導コイルによりトーチ内のガスをプラズマ状態にする ものであり，誘導結合型放電によって熱プラズマを発生する。

$\mathrm{RF}$ 熱プラズマの特色は, 大きな直径 $(5-10 \mathrm{~cm}$ 程度)のプ ラズマであること，およびガス流速が DC アークに比べて 1 桁程度低いことである。そのためにプラズマ内における処理 物質の滞留時間を長くすることができる。プラズマジェット 内の物質の滞留時間は 1 ミリ秒程度であるが， RF 熱プラズ マの滞留時間は 10 ミリ秒程度である。よってプラズマ中の 加熱や分解反応の進行を充分行うことができる。さらに各種 の反応性ガスを使用して, 酸化雲囲気や還元䨌囲気を自由に 選択することができる。

しかし無電極放電である $\mathrm{RF}$ 熱プラズマは，外的じょう乱 には敏感であることが短所となる。 RF 熱プラズマによる材 料プロセッシングでは，トーチに導入する原料によってプラ ズマが不安定にならないように，処理物質の量を制限しなく
てはいけない。

$\mathrm{RF}$ 熱プラズマは高融点物質であっても瞬時に蒸発させる ことができるという特長を利用する成膜プロセッシングとし て，立方晶窒化ホウ素 (c-BN) の大気圧下の合成がある。 c-BN はダイヤモンドに次ぐ硬さと高い熱伝導率を持ち, 高 温下において鉄系材料との反応性が小さいことから切削工具 向けの新たなコーティング材として期待されている。しかし 既存の c-BN 合成方法では, 原料ガスとして $\mathrm{B}_{2} \mathrm{H}_{6}, \quad \mathrm{BF}_{3}$ など の毒性, 腐食性や爆発性を有するものが多く, 工業的応用が 困難である。 $\mathrm{Ar}-\mathrm{N}_{2}$ あるいは $\mathrm{Ar}-\mathrm{NH}_{3}$ プラズマ中に安全な原 料である h-BN 粉体を供給することによって c-BN が合成さ れている。基板へバイアス電圧を印加することによって, 図 6 に示すような c-BN の形成と窒化反応を促すことが可能と なり，大気圧でも c-BN を合成することができる ${ }^{12)}$

$\mathrm{RF}$ 熱プラズマの新しい展開として，パルス変調 $\mathrm{RF}$ 熱プ ラズマによる非平衡性の顕在化がある。これは RF 熱プラズ マの発生に対して時間的なダイナミック制御を行う方法であ

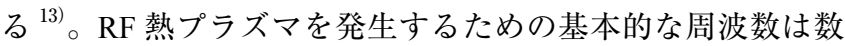
$\mathrm{MHz}$ であるが, このコイル電流をミリ秒オーダーの周期で 振幅変調すると, 熱プラズマの特徴である高温反応場と, 低 温場の遷移過程含んだ新しい反応場を意困的に繰り返すこと ができる。

熱プラズマの持つ高エネルギー状態を維持しながら, トー タルの入力エネルギーを軽減できるだけではなく，高速な状 態遷移にともなう非平衡性を実現することが可能となり，高 濃度の活性化学種の生成が期待できる。LTE 状態の熱プラズ マの場合には, 高活性の気相種は高温領域でしか存在できな いが，熱プラズマに非平衡性を導入することによって，比較 的温度が低い領域でも高活性の気相種を発生することが可能 となる。つまり, 熱プラズマの高温と高活性の特徵を活かし て, 高エネルギーを有する高濃度の気相種を高速で堆積させ

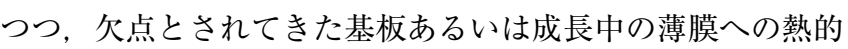
なダメージを抑制できる。

プラズマによる窒化処理は, 高温でしか存在できない活性 なラジカルを低温でも存在させることが必要なプロセッシン グである。窒素を含有したプラズマを用いて窒化処理を行う

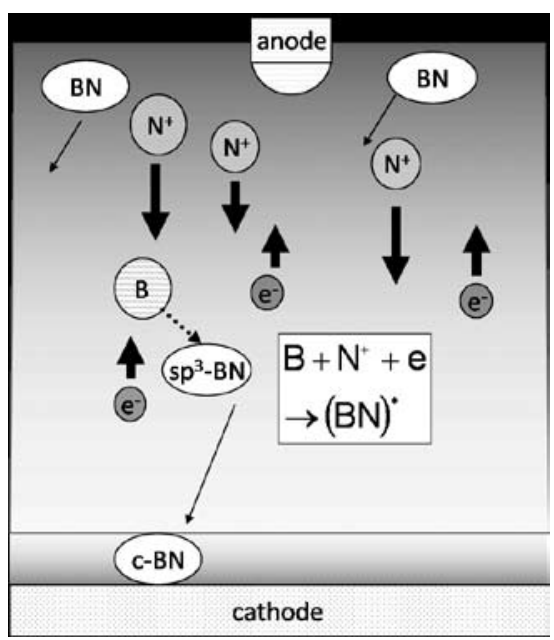

図 6 c-BN の形成と窒化反応 
ときは，窒化処理で重要な役割を担っている $\mathrm{N}, \mathrm{N}^{+}$などの 高温で安定な活性種の濃度と, プラズマの温度の制御が重要 である。これらを独立に制御することはLTE プラズマでは 困難であるが，パルス変調 $\mathrm{RF}$ 熱プラズマを用いることに よって, 低温の基板に供給される窒素ラジカルを増大できる ことが, 励起窒素原子からのスペクトル放射強度の計測に よって示されている ${ }^{14)}$ 。窒化処理物質の熱的なダメージを 低減して, 高い反応性を保持したままの活性種の濃度を増大 させることができれば，窒化処理の適用範囲を広げることが できる。酸素や水素原子は $3000 \mathrm{~K}$ 以下で分子に再結合するが, 窒素原子はさらに高温の $7000 \mathrm{~K}$ で再結合してしまうことを 考えると, パルス変調 RF 熱プラズマによる非平衡性の導入 は，窒素ラジカルの活用において効果であると考えられる。

処理物質の温度上昇を抑えながら, 高活性のラジカルを必 要とする材料プロセッシングとして, 酸化亜鉛への水素ドー プがある ${ }^{15)}$ 。室温で発光する紫外レーザー, 紫外発光ダイ オードとして酸化亜鉛の応用に関する研究が盛んに進められ ているが，この酸化亜鉛の励起子発光効率の向上，レーザー 発振間値の低減には, 酸化亜鉛に高濃度の水素をドープする ことが有効である。熱平衡状態では水素ラジカルは拈よそ $3000 \mathrm{~K}$ 以上の高温領域にしか存在できないので，通常の熱 プラズマでは水素ドープ中の酸化亜鉛の温度上昇を避けるこ とができない。パルス変調 RF 熱プラズマの場合は，プラズ 又処理時の水素濃度と投入する全熱量をそれぞれ独立に制御 できるので，酸化亜鉛の熱的なダメージを抑制しながら，高 濃度の水素をドープすることが可能となる。

\section{4. 多相交流放電による材料プロセッシング}

直流放電の代わりに多相交流放電を用いると, 複数のトー チ間に容易にアークを発生させることができる。3 相アーク 放電は産業的に広く用いられているが, 最近は 6 相や 12 相 などの多相放電アークを用いた材料プロセッシングの研究が 行われている ${ }^{16)}$ 。图 7 に示すように 12 本の電極に位相の異 なる多相交流を印加することにより, 電極先端部で囲まれた 領域全体にアーク領を発生することができる。このような多 相放電アークは根本的に 3 相アークとは異なり, 多数の電極

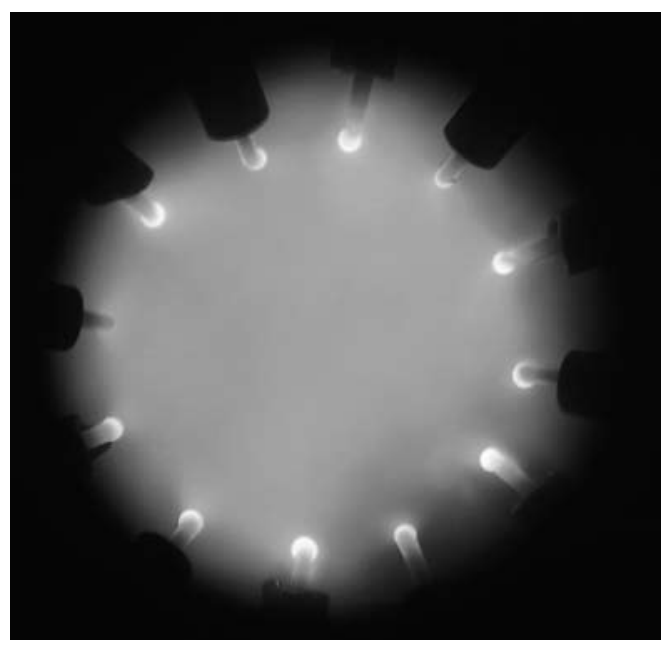

図 712 相交流アークの放電の様子
間で均一な放電領域を形成する放電方式である。多相放電 アークは直径が $100 \mathrm{~mm}$ 以上のアークを発生することができ， エネルギー効率が高いことが利点である。多相放電アークは, DCアークよりもプラズマ体積が大きく, $\mathrm{RF}$ 熱プラズマよ りも低コストで高効率という利点がある。

多相放電アークによる材料プロセッシングとしては, 最近 開発されたインフライト溶融によるガラス製造がある。イン フライト溶融によるガラス製造は, 従来のシーメンス炉の複 雑な原料溶融過程を一本の熱プラズマで置き換えてしまう方 式であり, 熱伝達の高効率化, 設備の省スペース化, プロセ スの飛躍的な単純化を可能としている。現在の多くのガラス 製品が製造されている大型の溶融炉では, 未溶融物の解消, 気泡の除去, 組成の均質化などのために, 融液を $1 \sim 6$ 日間 程度滞留させて, 気泡のない均質なガラス融液に変えている。 このような長時間の溶融が多量のエネルギー消費の原因と なって抢り, 我が国のガラス産業は, 全産業の約 $1 \%$ に相当 するエネルギーを消費している。

インフライト溶融によるガラス製造は, 特にガラス溶融工 程に必要なエネルギーコストを削減することを目的として開 発されている ${ }^{17)}$ 。これは造粒したガラス原料を多相アーク などの熱プラズマ中で瞬時に溶融する方法である。この技術 が成功すれば大半のガラス製造に適用することが可能となり， 溶融炉の大幅な小型化と消費エネルギーの大幅な削減が期待 できる。ガラス原料粒子を熱プラズマの高温場を飛翔させて， 短時間で溶融を終了させるインフライト溶融技術は, 工業的 な意味だけでなく, 学術的な観点からも非常に興味深いもの である。通常のプラズマ溶射では粒子を単に加熱, 溶融する ことが主であり, ガラス反応のように複雑な反応をプラズマ 中の数ミリ秒の滞留時間で完結させるような研究はほとんど 行われてこなかった。

ガラス原料溶融に必要なエネルギーを可能な限り削減する ためには, 多相放電アークだけではなく, 多相放電アークと 燃燒炎の複合加熱源を用いる方法も研究されている。熱プラ ズマとしては, 原料粒子の滞留時間を長くすることが可能な $\mathrm{RF}$ 熱プラズマを用いることも可能であるが, $\mathrm{RF}$ 熱プラズマ によるインフライト溶融処理のエネルギー効率は低いことか ら, 多相放電アークを用いるプロセッシングのほうがエネル ギー削減には適していると考えられる。

\section{5. おわりに}

熱プラズマの新たな可能性を見出し, 産業的応用への展開 を目的として, 熱プラズマの非平衡性と高温を利用した材料 プロセッシングを紹介した。

熱プラズマの高温という特長を利用する産業応用としては, 溶接や溶射があり, 最近は廃棄物処理への応用も広がりつつ ある。熱プラズマを用いるナノ粒子製造でも工業生産技術と して成功している例があるが, 熱プラズマによって処理対象 物を単に溶融あるいは蒸発するだけのプロセッシングがほと んどである。プラズマ溶射がすでに工業的技術として完成し ているように，高温を利用するだけの技術開発には限界があ り，熱プラズマの高温を利用する方法には新たな展開がない と思われていた。しかし，最近になって開発されたインフラ 
イト溶融によるガラス製造のように，熱プラズマが有する高 温を使うだけのプロセッシングでも，インフライト処理中の 粒子内の物質移動, 反応, 熱移動を制御することによって, 新しい工業的技術への展開が可能であることが示されている。 今後は熱プラズマの高温効果に加えて, 非平衡効果を活用す ることによって，工業生産技術につながる材料プロセッシン グの新たな展開が拓かれることを期待する。

(Received March 19, 2009)

\section{文献}

1 ) Y. Tanaka and T. Watanabe; J. Plasma Fusion Res., 82, 479 (2006) (in Japanese).

2 ) T. Watanabe; J. Plasma Fusion Res., 85, 83 (2009) (in Japanese).

3 ) N. Atsuchi, M. Shigeta and T. Watanabe; Inter. J. Heat Mass Transfer, 49, 1073 (2006).

4 ) T. Watanabe, N. Atsuchi and M. Shigeta; Inter. J. Heat Mass Transfer, 49, 4867 (2006).

5 ) Z. Duan and J. Heberlein, J. Therm. Spray Tech., 11, 44 (2002).

6 ) T. Watanabe, X.C. Wang, J. Heberlein and E. Pfender; Thin Solid Films, 316, 169 (1998).
7 ) E. Pfender; Plasma Chem. Plasma Processing, 19, 1 (1999).

$8)$ Z. Duan, L. Beall, J. Schein, J. Heberlein and M. Stachowicz; J. Thermal Spray Tech., 9, 225 (2000).

9 ) S. Russ, E. Pfender and P. J. Strykowski; Plasma Chem. Plasma Processing, 14, 425 (1994).

10) T. Watanabe; J. Surface Finishing Soc. Japan, 59, 718 (2008) (in Japanese).

11) T. Watanabe, H. Itoh and Y. Ishii; Thin Solid Films, 390, 44 (2001)

12) T. Watanabe, R. Sataka and K. Yamamoto; Thin Solid Films, 516, $4462(2008)$

13) T. Ishigaki, X. Fan, T. Sakuta, T. Banjo and Y. Shibuya; Appl. Phys. Lett., 71, 3787 (1997).

14) T. Tanaka, T. Uesugi and T. Sakuta; Plasma Sources Sci. Technol., 16, 281 (2007)

15) N. Ohnishi, T. Ishigaki, N. Okada, T. Sekiguchi, I. Sakaguchi and H. Haneda; Appl. Phys. Lett., 80, 2869 (2002).

16) T. Matsuura, K. Taniguchi and T. Watanabe; Thin Solid Films, 515, $4240(2007)$

17) Y. Yao, T. Watanabe, T. Yano, T. Iseda, O. Sakamoto, M. Iwamoto and S. Inoue; Sci. Tech. Adv. Mater, 9, 025013 (2008). 